\title{
A Review of Pyrolisis of Eceng Gondok (Water hyacinth) for Liquid Smoke
}

\author{
Rita Dwi Ratnani ${ }^{1,4^{*}}$, Widiyanto ${ }^{3}$ \\ ${ }^{1}$ Doctoral Program of Environmental Science, School of Postgraduate Studies, Diponegoro University, Semarang - Indonesia \\ ${ }^{2}$ Department of Chemical Engineering, Faculty of Engineering, Diponegoro University, Semarang - Indonesia \\ ${ }^{3}$ Department of Animal Sains, Faculty of Animal Sains and Agriculture, Diponegoro University, Semarang - Indonesia \\ ${ }^{4}$ Department of Chemical Engineering, Faculty of Engineering, Wahid Hasyim University, Semarang - Indonesia
}

\begin{abstract}
The growth of eceng gondok (Water hyacinth) in Rawa Pening Lake showed rapid increase.. Based on the mandate of the National Lake conference in Bali and the 16th World Lake Conference, Rawa Pening is one of the fifteen national lakes which need to be treated for its conservation. Reducing number of eceng gondok plants is one of the alternatif. However, further processing is required to treat the waste of eceng gondok. One attempt is to convert eceng gondok (water hyacinth) into liquid smoke product. This article reviewes the potency of eceng gondok for liquid smoke through pyrolisis method. The liquid smoke can be used for various applications such as preservatives, antioxidants, biopesticides and perisa disinfectants. Pyrolysis is a combustion process in the absence of oxygen to produce liquid and charcoal activated charcoal products called activated charcoal. The pyrolysis process is generally carried out at a temperature range between $200-700{ }^{\circ} \mathrm{C}$. The pyrolysis process is one of the methods chosen in order to strive for development that suppresses the formation of $\mathrm{CO}$ gas but releases water vapor. Pyrolysis at a temperature of 300-700 ${ }^{\circ} \mathrm{C}$, produces the most dominant compounds 1.6 Anhyro-beta-d-glucopyranose, phenol, and acetic acid. The reaction that occurs during pyrolysis of this temperature is the release of water vapor instead of carbon gas so that it is safe for the environment. The discussion on this article focused on the production of liquid smoke from eceng gondok biomass.
\end{abstract}

Keywords : water hyacinth; liquid smoke; pyrolisis

\section{Introduction}

Rawa pening is one of fifteen lakes that are a priority to be conserved for its sustainability. Rawa Pening has high biodiversity, but eceng gondok (Water hyacinth) is the most dominant plant in the ecosystem. It is estimated that water hyacinths that live floating on the surface of the water cover the lake surfaces around 1,080 ha or approximately $85.4 \%$ of the lake area in 2006 [1]. Based on the sedimentation rate, it is predicted that eceng gondok will cover all the water surface in Rawapening Lake in 2021. Therefore, various efforts to overcome the uncontrolled rapid population of water hyacinth are carried out, however the result was not optimum yet.

There have been several activities to utilize water hyacinth, including: for handycrafts, organic fertilizer, biogas [2], animal feed [4], biological control efforts are also carried out by using herbivorous grass carp/Ctenopharyngodon idela [5]. Furthermore, eceng gondok is also potent for soil enrichment, traditional medicine, animal feed, mushroom cultivation media, making furniture, processing coffee beans, detergent, paper, briquettes, adsorbents of lead, arsenic and mercury, making cellulose enzymes and food sources for aquatic fauna such as snails, fish and crabs [5], activated carbon [6], biodiesel, bioethanol [7]. Since eceng gondok also contains high cellulose $(20 \%)$, make this plant is potential source for liquid smoke which can be processed thorugh pyrolisis method. The pyrolysis process is one of the methods chosen in order to strive for development that suppresses the formation of $\mathrm{CO}$ gas but releases water vapor [8].

\section{Pyrolysis}

Pyrolysis is the initial process that occurs when the first organic material is heated in the absence of oxygen to produce flammable gas. Pyrolysis of organic materials such as biomass is conducted at high temperatures to form charcoal, tar and smoke/vapor which can be condensed into liquid smoke also known as bio-oil, biocrude [9]. Biomass pyrolysis into liquid smoke that has been widely studied are: acacia wood [10]; coconut shell [11,13] shell and coconut fiber [12] nyamplung [14]; corn cobs [15]; durian skin [16]; counterfeit wood waste [17]; oil palm shells [18]; solid organic waste [19]; sengon wood [20]; pine wood waste [21], pine wood waste with Mo/clay catalyst [22], walnut shell [23]; Solid waste of palm starch [24]. The composition of liquid smoke produced according to [10] is influenced by various factors, including the type of material, the moisture content of the material and the pyrolysis temperature used.

Pyrolysis is the destruction of biomass by heat in the reactor vacuum. Process pyrolysis usually takes place at a temperature of $200-700{ }^{\circ} \mathrm{C}$. This process will convert biomass into solid fuel (charcoal/char), liquid fuels (Tar), and fuel gas $\left(\mathrm{H}_{2}\right.$ and $\left.\mathrm{CH}_{4}\right)$ [25]. Pyrolysis also produces

* Corresponding author: ritadwiratnani@ unwahas.ac.id 
oil-biomass such as bio-oil, oil bio-raw, oil bio-fuel, liquid wooden, and wood oil. Bio-oil can be used as fuel in the boiler, diesel engine or gas turbine to heat and power generation [24]. Bio-oil from pyrolysis of chicken waste has also been investigated, but the yield is lower than in bio-oil resulting from biomass. This is due to chicken waste contains high ash content. Biomass is renewable resources and has received great attention due to environmental considerations and increasing energy demand around the world. The carbon dioxide $\left(\mathrm{CO}_{2}\right)$ produced by biomass will be recycled into the plants in the process of photosynthesis.

Processing pyrolysis for the production of liquid smoke can use raw materials such as variety of wood species, palm, coconut shell, hull, pulp or sawdust wood and so forth. During burning, components of the wood will experience the burning of imperfect produce a wide range of compounds, among others phenol, carbonyl, acid, furans, alcohol, lakton, hydrocarbons, polisiklik aromatic and so forth. Smoke is a complex system consists of phase liquid dispersed and medium gas as dispersing. Reactions that occur in the process of pyrolysis among others: decomposition of polymer into organic compounds at low molecular weight because the influence of heat which includes the oxidation reaction, polymerization and condensation.

Pyrolysis of wood waste already contains synthetic materials, polyurethane, and varnish polyester researched potential for convertible into liquid fuel renewable. Composition of the product was influenced by varnish type. The results of bio-oil maximum of $46.7 \%$ obtained from pyrolysis of wood waste containing varnish polyester temperature pyrolysis the end of $500{ }^{\circ} \mathrm{C}$. Bio-oil resulting from wood waste containing varnish mainly consists of phenol, alcohol, ketones, acid, aldehydes, benzene. Therefore, bio-oil resulting from pyrolisis of wood waste can be a substitute for biofuels and green chemicals [27].

Pyrolysis of organic solid waste has been successfully conducted to produce liquid smoke at the yield of 32.87$34.67 \%$, $\mathrm{pH} 3.8-4.8$ and total phenol of $6.15 \times 10^{-3}-$ $2,24 \times 10^{-2} \%$. The higher temperature pyrolysis leads to the increase of phenol total and achieve the optimum at temperature of $505{ }^{\circ} \mathrm{C}$. The compoundes identified in the product were 61 compounds [19].

Pyrolysis of wood waste and bamboo have also been studied. Pyrolysis was operated at a temperature of 110$500{ }^{\circ} \mathrm{C}$. This condition, the liquid smoke is generated as well as charcoal, and tar. The highest yield was obtained from wood waste bamboo $(62.89 \%)$, waste pine wood $(58.33 \%)$, and waste teak wood $(55.20 \%)$. The highest acid levels were obtained from bamboo wood $(23.02 \%)$, teak wood $(18,58 \%)$. The highest total phenol was achived at $205.711 \mathrm{mg} / \mathrm{L}$ by bamboo wood waste. While the largest chemical components was shown by pine wood waste in the form of 2 propanon (CAS) acetone $35.06 \%$ and acetic acid $31.65 \%$ [25].

Pyrolysis of pine wood waste has also been studied by [21]. The pyrolysis pine wood waste is optimum at temperature of $500{ }^{\circ} \mathrm{C}$ with $52.1 \%$ by weight on the condition of vacuum. Pyrolysis can beconducted by using catalyst. Research using NiMo/NZA was done by impregnation of metal into zeolite and could increase the catalytic efficiency and yield of bio-oil [28].

\section{Water hyacinth}

Water hyacinth is a plant that grow in swamp or water, and it is floating on the surface water (Fig 1). In the water ecosystem, the water hyacinth can grow rapidly (3\% per day). The rapid growth of water hyacinth cause number of trouble such as disruption of transportation, narrowing of the river, and other problems due to their spread covering the surface of the river or waters. Moreoover, water hyacinth is very difficult to be controlled of their population because of its growth very quickly and high endurance of life. The potency of Water hyacinth as liquid smoke and bioenergy has been investigated. It is in prove with a study conducted by [5, 8] which stated that the water hyacinth can be processed into biofuel so it can be hopeful for alternative energy in the $21^{\text {st }}$ century plant water hyacinth fresh contains $95.5 \%$ water, $3.5 \%$ organic materials, $1.0 \%$ ash, $0.20 \% \mathrm{~K}_{2} \mathrm{O}$, $0.04 \% \mathrm{~N}$, and $0.06 \% \mathrm{P}_{2} \mathrm{O}_{5}$. From the base of water content, $75.8 \%$ organic materials, $1.5 \% \mathrm{~N}$ and $24.2 \%$ ash. Ash it containing protein containing $7.2 \mathrm{~g}$ leucine, $5.34 \mathrm{~g}$ lysine, $4.72 \mathrm{~g}$ phenylalanine, $4.32 \mathrm{~g}$ treonin, $4.32 \mathrm{~g}$ isoleusin, $0.72 \mathrm{~g}$ methionine, and $0.27 \mathrm{~g}$ valin.

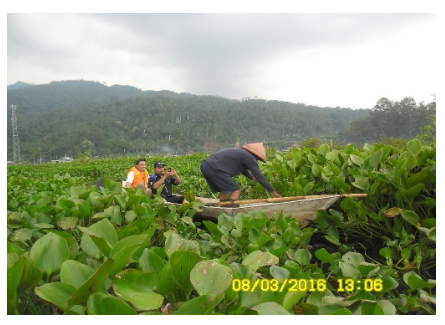

Fig.1 Water hyacinth on Rawa Pening

Great potential of water hyacinth as bioenergy was studied because water hyacinth contains low lignin (10\%) and contains high amount of cellulose (20\%) and hemicellulose $(33 \%)$. Biomass generally that came from land plant can have a $30-50 \%$ of cellulose, $20-40 \%$ hemicellulose and $15-30 \%$ of lignin. On the herbs, lignin (consists of a group fenilpropanoid) acts as a polymer around hemicellulose mikrofibril, binding molecules cellulose together and degradation chemistry. Lignin can not be converted into sugar. So, bioenergy can't be made from biomass containing high lignin.

Water hyacinth have low lignin contens, which means that cellulose and hemicellulose are more easily converted to sugar and then fermented into bioethanol. Furthermore, water hyacinth grows very quickly and contains high nitrogen content. Because of high nitrogen content then this biomass can be used to produce biogas and by product for organic fertilizer. Water hyacinth that has a high nitrogen content can be converted into liquid smoke using pyrolysis method. Another potential is due to content of lignin, the water hyacinth potentially be pyrolysed into oil in the form of liquid smoke. 


\section{Liquid Smoke}

Liquid smoke is the result of condensation of the biomass pyrolysis process. The results of pyrolysis of biomass contain carbonyl, phenol and acid compounds. These compounds are the result of heat degradation of the components of lignin, cellulose, and hemicellulose. Carbonyl, phenol and acid compounds in liquid smoke have a contribution in providing aroma, color, flavor and antioxidant and antimicrobial. This antioxidant and antimicrobial content make this liquid smoke can act as a preservative [14].

The thermal decomposition of lignin will produce phenol and etherfenolic which play a role in giving aroma and showing antioxidant activity such that it can extend the shelf life of the fumigation product. Phenol is produced from the decomposition of lignin which occurs at a temperature of $300{ }^{\circ} \mathrm{C}$ and ends at $400{ }^{\circ} \mathrm{C}$. The aroma compounds in question are guaikol (2-methoxy phenol), syringol (1,6-dimethoxy phenol) and its derivatives [29]. The results of cellulose pyrolysis are acetic acid and carbonyl consisting of acetaldehyde, glycol and acreolin. Acid content in liquid smoke can affect flavor, $\mathrm{pH}$, shelf life and anti-bacteria. Existing acid compounds include acetic acid, propionate, butyrate and valerate. Carbonyl compounds derived from cellullose can react with proteins and form a brown color, which has a role in the coloring and taste of the product. This group of compounds has a scent like a unique caramel aroma. Pyrolysis hemicelluloses if produces furfural, furans, and their derivatives and carboxylic acids. The decomposition of hemicellulose occurs at a temperature of $200-250{ }^{\circ} \mathrm{C}$.

Liquid smoke is produced from various woods, namely hardwood and softwood. This type of hardwood has high lignin content, so the phenol content produced from pyrolysis is also high. The production of liquid smoke from coconut shells that has been thoroughly researched produces liquid smoke with high phenol levels because coconut shell is a type of hardwood. This is because coconut shells have higher lignin content compared to lignin levels from sengon wood. As reported by [20] that sengon wood is one of the softwoods. Sengon wood is softer than coconut shell. From the data obtained that the lignin content in coconut shell is $46.29 \%$ higher than sengon wood which is only $26.8 \%$. However, it turns out that the levels of lignin, cellulose and hemicellulose differ also depending on the type and variety of coconut shell, moisture, soil, source of wood and age of coconut shell. According to the results of the study [30], that lignin levels were $28.86 \%$, cellulose $27.43 \%$ and hemicellulose $27.08 \%$. The test results are the same as those studied by previous researchers that coconut shell has a lignin content of coconut shell is $23.84 \%$, cellulose $33.61 \%$ and hemicellulose around $29.27 \%$.

Liquid smoke with another name bio oil can be used in various applications both non-food and food. For nonfood purposes such as to clump latex and prevent the appearance of smells and growth of fungi, coagulant in processing raw rubber, preserving wood, preserving wood, increasing plant growth, insect killers, liquid fuels, burning burns, and treatment. Clumping latex and preventing odor and fungal growth on sit latek sheets [29]. Liquid smoke or in other names bio oil is a liquid formed from condensation of smoke produced from pyrolysis of wood and other lignocellulosic materials in an anaerobic pyrolisator [31].

Liquid smoke from pyrolysis results of oil palm empty fruit bunches has also been investigated by [32] which carried out pyrolysis for 8 hours at $400{ }^{\circ} \mathrm{C}$ containing $5 \%$ phenol and $0.454 \%$ acetic acid managed to become a coagulant in processing raw rubber. The results obtained are better than the treatment of adding formic acid and battery water. Other studies regarding the use of liquid smoke made from corn cobs proved to have the highest yield of $48 \%$ and phenol compounds and acetic acid compounds $6.73 \%$ and $84.45 \%$ [33] so that it is effective for preserving wood.

Based on the report on the research conducted [34] that by giving liquid smoke produced from pyrolysis of smoke, looking for empty palm oil bunches can improve the growth of cacao growth better in parameters of seed height and stem circumference. Liquid smoke as an insecticide has been studied by [35]. Laboratory experiments proved that grade 2 liquid smoke from native coconut shells was highly toxic to brown planthopper (Nilaparvata lugens) and phytotoxic in rice plants. Liquid smoke can be used for liquid fuels. Based on research conducted by [10], that acacia wood (Acacia Mangium Mill) is hydrolyzed at $400{ }^{\circ} \mathrm{C}$ and 90 minutes sampling time has the potential to become liquid fuel. Biodiesel from liquid smoke that is processed from the skin and coconut shell with Machine 6.5 HP which is capable of running a diesel engine with performance that is not much different, clearer, no smell and lighter engine speed [12].

Liquid smoke that can be used for food product is liquid smoke that has been distilled and purified using the adsorbent zeolite or activated carbon. The results of liquid smoke that has been distilled then was analysed using GC-MS. After analysis with GC-MS, liquid smoke grade 2 have 11 compounds from class phenol, acid and carbonyl and proven properties bacteriostatic of value mic (levels inhibitory minimum) 6\%. Utilization of liquid smoke on food products of them are as anti bacteria in: preservatives know, Eels, and processed steak, know and meatballs, tuna, fish pindang, cork and tuna. Utilization for liquid smoke for food product has been applied in the increases shelf life.

Preserve Tofu and meatballs by using a combination of liquid smoke and chitosan with $1.5 \%$ concentration and $2.5 \%$ chitosan able to extend life for three days [36] study to determine the activity of anti-oxidants and antimicrobial liquid smoke nanocapsul of coconut shell using maltodextrinadn chitosan as enkapsulan and its application in the preservation of tuna has been done by [37]. The result investigation shows that the liquid smoke nanocapsul proven efectiv the antioxidant on tuna fish. Therefore, nano enkapsulation promising for the application of food. Liquid smoke can be used to preserve the fish pindang. In the treatment of the addition of liquid smoke $1 \%, 2 \%$ or $3 \%$ in storage 3 rd day to- 7 around 3.1.10 $-9.3 .10^{4} \mathrm{CFU} /$ grams still in the threshold according to the requirements SNI 01-2717-1992, that is to the quality of microbiology fish pindang with TPC per gram maximum $1.10^{5} \mathrm{CFU} /$ grams. Fish pindang be durable due to absorb substances components smoke like aldehyde, 
phenol, and organic acids other which is the substances preservatives because are toxic for bacteria. Combination of functional components phenol and content of organic acids high enough work synergistically prevent and control the growth of microbial. The content of acid levels high can inhibit the growth of microbial because microbial can only grow on acid levels low [38] study conducted by [39] reported that liquid smoke Wood galam (malaleuca leucadendra) in the form of biodegradable film able to maintain the quality of Cork/Gabus better on testing microbiological especially on the value of the TPC and coliform while on the value tuna fish did not leave a significant effect on the quality of fish for storage 10 days at a temperature of $\pm 4^{\circ} \mathrm{C}$. Utilization of liquid smoke to preserve the tuna has also been studied by [40] has been successfully preserve tuna with the best results storage time 2 days at room temperature with a long time submersion 2 hours by using liquid smoke resulting from pyrolysis coconut Shell. Liquid smoke can be produced by the method pyrolysis as measures to reduce emissions in a combustion process.

\section{Conclusion}

Various studies have been carried out aimed at the production of liquid smoke from new generation biomass through different materials. By considering the production of liquid smoke with different ingredients while overcoming the hyacinth bloom for the creation of swamps protected by the environment. Liquid smoke which also has another bio-oil name, can be used in various uses both non-food and food. For non-food purposes such as to clump latex and prevent the appearance of smells and growth of fungi, coagulants in the processing of raw rubber, preserving wood, preserving wood, increasing plant growth, insect killers, liquid fuels, burning burns, and treatment. As for food products, liquid smoke functions as anti bacteria. In some studies functioned as tofu preservatives, eels, and processed steaks, tofu and meatballs, pindang, cork and tuna. The pyrolysis process is generally carried out at a temperature range between $200-700{ }^{\circ} \mathrm{C}$. The reaction that occurs during pyrolysis at this temperature is the release of water vapor instead of carbon gas so that it is safe for the environment.

\section{References}

1 T. R. Soeprobowati, "Mitigasi Danau Eutrofik: Studi Kasus Danau Rawapening" in Prosiding seminar nasional Limnologi VI tahun 2012, pp. 36-48 (2012)

2 A. Yonathan, A. R. Prasetya, B. Pramudon, "Produksi Biogas Dari Eceng Gondok (Eicchornia Crassipes): Kajian Konsistensi dan $\mathrm{pH}$ Terhadap Biogas yang dihasilkan," J. Teknol. Kim. dan Ind., 1, no. 1, pp. 412-416, (2012)

3 R. Rompas, B. Tulung, J. S. Mandey, M. Regar, "Penggunaan Eceng Gondok (Eichhornia Crassipes) Terfermentasi Dalam Ransum Itik Terhadap Kecernaan Bahan Kering Dan Bahan Organik,'J. Zootek “Zootek”Jurnal, 36, no. 2, pp. 372-378, (2016)

4 A. Nontji, danau danau alami, 1st ed. Jakarta, 2016)
5 A. Bhattacharya, P. Kumar, "Water Hyacinth as a Potential Biofuel Crop," EJEAFChe, 9, no. 1, pp. 112-122, (2010)

6 R. D. Ratnani, "Proses Pirolisis Eceng Gondok (Eichhornia Crassipes) Menjadi Karbon Aktif Dengan Bahan Pengaktif Natrium Klorida ( $\mathrm{NaCl})$," Momentum, 1, no. 1, pp. 5-10, (2005)

7 C. V. Sagar, N. A. Kumari, "Sustainable Biofuel Production From Water Hyacinth (Eicchornia Crassipes)," Int. J. Eng. Trend Technol., 4, no. 10, pp. 4454-4458, (2013)

8 A. J. L. Rasi, Y. P. Seda, " Potensi Teknologi Asap Cair Tempurung Kelapa terhadap Keamanan Pangan," Jurnal eUREKA, 1, no.1, pp. 1-10, (2017)

9 S. Sadaka, A. A. Boateng, "Pyrolysis and Bio Oil," Agric. Nat. Resour., pp. 1-25, (2017)

10 A. H. Surest, M. S. Reza, D. Priyayi, "Pembuatan Asap Cair Dari Kayu Akasia Dan Uji Awal Kemampuannya Sebagai Bahan Bakar Cair," J. Tek. Kim., 19, no. 4, pp. 38-44, (2013)

11 J. . Lombok, B. Setiaji, W. Trisunaryati, K. Wijaya, "Effect of Pyrolisis Temperature and Distillation on Character of Coconut Shell Liquid Smoke," Asian J. Sci. Technol., 5, no. 6, pp. 320-325, (2014)

12 R. Pamori, R. Efendi, F. Restuhadi, "Karakteristik Asap Cair dari Proses Pirolisis Limbah Sabut Kelapa Muda," Sagu, 14, no. 2, pp. 43-50, (2015)

13 C. Radhakrishnan, K. Natarajan, K. Azhagendran, K. Mohanlal, P. Ponraj, R. Nivas, "Experimental Analysis of Bio-Oil from Coconut Shell and Front by Continuous Pyrolysis Process," Int. J. Innov. Res. Sci. Eng. Technol., 5, no. 4, pp. 4841-4846, (2016)

14 S. Wibowo, "Characteristic of Smoke liquid from Nyamplung Shell," J. Penelit. Has. Hutan, 30, no. 3, pp. 218-227, (2012)

15 F. Swastawati, T. W. Agustini, Y. Darmanto, E. N. Dewi, "Liquid Smoke Performance of Lamtoro Wood and Corn Cob," J. Coast. Dev., 10, no. 3, pp. 1410 5217, (2007)

16 A. Rinaldi, A. Alimuddin, A. S. Panggabean, "Pemurnian Asap Cair Dari Kulit Durian Dengan Menggunakan Arang Aktif (Purification of Liquid Smoke From Durian Peel'S With Activated Charcoal)," Molekul, 10, no. 5, pp. 112-120, (2015)

17 A. Akbar, R. Paindoman, P. Coniwanti, "Pengaruh variabel waktu dan temperatur terhadap pembuatan asap cair dari kayu pelawan (Cyanometra cauliflora)," J. Tek. Kim., 19, no. 1, pp. 1-8, (2013)

18 L. Ginayati, M. Faisal, S. Suhendrayatna, "Pemanfaatan Asap Cair dari Pirolisis Cangkang Kelapa Sawit sebagai Pengawet Alami Tahu," J. Tek. Kim. USU, 4, no. 3, pp. 7-11, (2015)

19 A. G. Haji, Z. Alim, B. W. Lay, S. H. Sutjahjo, G. Pari, "Characterization of Liquid Smoke Pyrolyzed from Solid Organic Waste," J. Tek. Ind. Pertan., 16, no. 3, pp. 111-118, 2007.

20 N. R. L. A’yuni, P. Darmadji, Y. Pranoto, “Asap Cair Kayu Sengon sebagai Chelating Agents Logam Timbal $(\mathrm{Pb})$ pada Model Menggunakan Biji Kedelai (Glycine max)," Planta Trop. J. Agro Sci., 5, no. 1, pp. 42-51, (2017)

21 G. Ozbay, N. Ayrilmis, "Effect of Pyrolysis 
Temperature On Bio-Oil Production From vacuum Pyrolysis of Waste Froom Wood Industry," in Proceedings of 117th The IIER International Conference, Helsinki, Finland, 17th-18th August 2017, pp. 56-58, (2017)

22 M. A. A. Firman, S. Bahri, K. Khairat, "Pirolisis Biomassa Kayu Pinus (Wood Pine) Dengan Katalis Mo/Lempung Menjadi Bio-Oil," JOM FTEKNIK, 3, no. 1, pp. 1-11, (2016)

23 Yusnaini, Soeparno, E. Suryanto, R. Armunanto, "Physical, Chemical and Sensory Properties of Kenari (Canariun indicum L.) Shell Liquid Smoke-ImmersedBeef on Different Level of Dilution," J. Indones. Trop.Anim.Agric, 37, no. 1, pp. 27-33, (2012)

24 S. Sunarsih, Y. Pratiwi, Y. Suratno, "Pengaruh Suhu, Waktu dan Kadar Air pada Pembuatan Asap Cair dari Limbah Padat Pati Aren," in Prosiding Seminar Nasional Aplikasi Sains \& Teknologi (SNAST) Periode III, 1, no. 1, pp. 9-13., (2012)

25 W. Wijayanti, "Pengidentifikasian Entalpi Bahan Bakar Padat (Char) Dan Cair (Tar) Hasil Proses Pirolisis Biomasa," J. ROTOR, 7, no. 1, pp. 8-13, (2014)

26 M. Balat, M. Balat, E. Kirtay, H. Balat, "Main routes for the thermo-conversion of biomass into fuels and chemicals. Part 1: Pyrolysis systems," Energy Convers. Manag., 50, no. 12, pp. 3147-3157, (2009)

27 G. Özbay, A. Özçifçi, E. S. Kökten, "The Pyrolysis Characteristics of Wood Waste Containing Different Types of Varnishes," Turkish J. Agric. For., 40, no., pp. 705-714, (2016)

28 A. Saputra, S. Bahri, A. Amri, "Pirolisis Kayu Akasia menjadi Bio-Oil Menggunakan Katalis NiMo/NZA dengan Variasi Jumlah Pengembanan Logam dan Rasio Berat Katalis terhadap Biomassa," JOM FTEKNIK, 2, no. 2, pp. 1-6, (2015)

29 F. Kasim, A. N. Fitrah, E. Hambali, “Aplikasi Asap Cair Pada Lateks," J. Pasti, 9, no. 1, pp. 28-34, (2015)

30 S. Hartati, P. Darmadji, Y. Pranoto, "Penggunaan Asap Cair Tempurung Kelapa Untuk Menurunkan Kadar Timbal $(\mathrm{Pb})$ Pada Biji Kedelai (Glycine Max," Agritech, 35, no. 3, pp. 331-339, (2015)
31 T. Dickerson, J. Soria, "Catalytic Fast Pyrolysis: A Review," Energies, 6, no. 1, pp. 514-538, (2013)

32 A. Asmawit, H. Hidayati, N. Supriyatna, "Pemanfaatan Asap Cair Dari Tandan Kosong Kelapa Sawit Pada Pengolahan Karet Mentah," Biopropal Ind., 2, no. 1, pp. 7-12, (2011)

33 S. P. A. Anggraini, "Teknologi Asap Cair dari Tempurung Kelapa, Tongkol Jagung, dan Bambu sebagai Penyempurna Struktur Kayu," in Seminar Nasional Inovasi dan Aplikasi Teknologi di Industri, ITN Malang 4 februari 2017, pp. 1-6, 2017)

34 S. Yuniningsih, S. P. A. Anggraini, "Characterization of Liquid Smoke from Coconut Shell to $\mathrm{Be}$ Applicated as Safe Food Preservatives for Human Health," J. Agric. Food Technol., 3, no. 2, pp. 1-5, (2013)

35 F. X. Wagiman, A. Ardiansyah, Wicaksono Witjaksono, "Activity of Coconut-Shell LiquidSmoke as an Insecticide on the Rice Brown Planthopper (Nilaparvata lugens)," ARPN J. Agric. Biol. Sci., 9, no. 9, pp. 293-296, (2014)

36 R. Purba, S. H. Susesno, A. F. Izaki, S. Muttaqin "Application of Liquid Smoke and Chitosan as Natural Preservatives for Tofu and Meatballs," Int. J. Appl. Sci. Technol., vol. 4, no. 2, pp. 212-217, (2014)

37 S. Saloko, P. Darmadji, B. Setiaji, Y. Pranoto, "Antioxidative and antimicrobial activities of liquid smoke nanocapsules using chitosan and maltodextrin and its application on tuna fi sh preservation," Food Biosci., 7, pp. 71-79, (2014)

38 L. Widawati, B. Budiyanto, "Produce Liquid Smoke of Oil Palm Fruit Bunches for Preservative Boiled Salted Kembung Fish (Rastrelliger sp.)," $J$. AGROTEKNOLOGI, 8, no. 1, pp. 15-28, (2014)

39 R. Salima, N. Rahmia, "Pengaruh Asap Cair Kayu Galam ( Malaleuca leucadendra ) dalam Bentuk Biodegradable Film terhadap Pengawetan Ikan Gabus," J. Ris. Ind. Has. Hutan, 9, no. 2, pp. 75-90, (2018)

40 L. Hardianto, Yunianta, "Pengaruh Asap Cair Terhadap Sifat Kimia dan Organeleptik Ikan Tongkol (Euthynnus affinis)," J. Pangan dan Agroindustri, 3, no. 4, pp. 1356-1366, (2015) 